\title{
Ethnologies
}

The Heart of Cape Breton: Fiddle Music Recorded Live Along the Ceilidh Trail. Compiled, produced and annotated by Burt Feintuch. Recorded and mixed by Pete Reiniger. (Smithsonian Folkways SFW CD 40491, 2002, one compact disc and pp. 34 notes booklet).

\section{Sherry Johnson}

Volume 25, numéro 1, 2003

Négocier la transcendance / Negotiating Transcendence

URI : https://id.erudit.org/iderudit/007141ar

DOI : https://doi.org/10.7202/007141ar

Aller au sommaire du numéro

Éditeur(s)

Association Canadienne d'Ethnologie et de Folklore

ISSN

1481-5974 (imprimé)

1708-0401 (numérique)

Découvrir la revue

Citer ce compte rendu

Johnson, S. (2003). Compte rendu de [The Heart of Cape Breton: Fiddle Music Recorded Live Along the Ceilidh Trail. Compiled, produced and annotated by Burt Feintuch. Recorded and mixed by Pete Reiniger. (Smithsonian Folkways SFW CD 40491, 2002, one compact disc and pp. 34 notes booklet).] Ethnologies,

25(1), 291-296. https://doi.org/10.7202/007141ar d'utilisation que vous pouvez consulter en ligne. 
The Heart of Cape Breton: Fiddle Music Recorded Live Along the Ceilidh Trail. Compiled, produced and annotated by Burt Feintuch. Recorded and mixed by Pete Reiniger. (Smithsonian Folkways SFW CD 40491, 2002, one compact disc and pp. 34 notes booklet).

In comparison to other fiddle recordings, the concept of The Heart of Cape Breton: Fiddle Music Recorded Live Along the Ceilidh Trail is unique. In July 2000, producer, folklorist, and fiddler, Burt Feintuch, and Smithsonian Folkways sound supervisor, Pete Reiniger, loaded a van with recording equipment and spent eight days following the popular "Ceilidh Trail," otherwise known as Route 19, through Inverness County along the west side of Cape Breton Island. Their goal was to "record the music in the heart of the robust Cape Breton tradition, at dances, local concerts, and other music events..." (4). The result is "a snapshot of a week on the Ceilidh Trail” (13).

Although it includes several Acadian and First Nations communities, Inverness County has a primarily Scottish heritage. It has long been known in Cape Breton, and increasingly so outside this close-knit community, as a hotbed of traditional Cape Breton fiddle music. During my one-week stay in 1998 at the Gaelic College of Celtic Arts and Crafts in St. Ann's (http://www.gaeliccollege.edu), my Cape Breton fiddling-crazy colleagues and I spent every evening at a dance or concert somewhere in Inverness County. Although my trip was two years previous to Feintuch and Reiniger's recording tour, and included a slightly different line-up of musicians, this recording could be a soundtrack to that week. Certainly they have managed to capture the energy and enthusiasm of both musicians and audiences that I remember so well.

Quantitatively, this recording consists of 12 tracks, 11 musicians, including six fiddlers, 73 tunes, and a full 72 minutes of playing time. In his introductory essay, Feintuch provides an overview of Cape Breton fiddling and its social contexts, with a thumbnail history of the Island, its inhabitants, and music. He describes the distinctive Cape Breton piano accompaniment and dancing, and discusses the importance of fiddling in terms of social and economic capital.

Feintuch's notes for each track are extensive. First, he provides some introductory biographical information about the musicians, both fiddlers and back-up musicians, focusing on musical lineages and influences, particularly of family, and referring the reader to websites 
for follow-up reading. For the tunes themselves, he discusses alternate names and the significance of some of the names to the Cape Breton fiddle tradition. He identifies their composers where possible, and in what collections they may be found. Just finding names for many of these tunes is no small task; in this he was helped by Cape Breton fiddle scholar Kate Dunlay, who Feintuch acknowledges. Feintuch also provides descriptions of various tune genres (strathspey, jig, reel), for example, "Strathspeys are generally in 4/4 time. They inevitably include dotted rhythms..." (17), making this recording friendly for newcomers to Cape Breton fiddle music. Finally, the notes for each track conclude with a detailed description of the context of the event, and hence the recording. The recordings represent seven different events: the Ceilidh Trail School concert, Port Hood Arena dance, Mabou Hall dance, Broad Cove Scottish concert, Glencoe Mills dance, Mabou Hall ceilidh, and Brook Village Hall dance. A small criticism - I wish Feintuch had included a map locating the different events to help readers understand the physical relationship between the various locales.

With regard to instrumental technique, the notes are uneven. Some comments provide important insights. For example, of Betty Beaton's piano accompaniment, Feintuch writes: "Listen to the way she occasionally doubles the melody with her right hand while keeping a solid beat with the left" (18). Yet other comments are overly general: "listen to Jackie's strong, creative piano accompaniment" (24), "no one plays dance music better than Kinnon and Betty" (27). As a fiddler and music scholar, I would have liked to see more musical analyses of the performances, but perhaps that is beyond the intended scope of this project.

One of the strengths of this recording is the opportunity to hear from a variety of fiddlers (Brenda Stubbert, Jackie Dunn MacIsaac, Kinnon Beaton, Jerry Holland, Buddy MacMaster, and Wendy MacIsaac) and accompanists (pianists Richard Wood, Wendy MacIsaac, Betty Beaton, Allan Dewar, Joey Beaton, Jackie Dunn MacIsaac, and guitarist Brian Doyle), who present a variety of tunes and styles, representing various musical lineages, from different parts of the Island. One of the inherent disappointments of an anthology-style recording is that two or three tracks from each set of musicians merely whet our appetite for more. Anticipating this, Feintuch provides a discography of recent recordings by the musicians featured on this $\mathrm{CD}$, as well as a bibliography of recent tune collections and books on fiddling for those interested in 
further reading. Because many of the locally-produced recordings of Cape Breton music can be difficult to find off the Island, he also includes the contact information for a number of local mail-order companies.

Feintuch describes the fiddlers on this recording as "many of the best known, most admired, and most influential Cape Breton fiddlers and accompanists. These are musicians profoundly rooted in their culture, representatives of a tradition that runs deep" (13). Nonetheless, they are not North American household names the way, say, Natalie MacMaster and Ashley MacIsaac are. I congratulate Feintuch for sticking with some of the lesser-known (outside of Cape Breton and fiddling circles only) fiddlers, rather than waiting for one of the bigger names to appear at these local venues, as they occasionally do when their touring schedules permit. While including Natalie or Ashley in the line-up might have been a wise marketing decision, instantly appealing to a more mainstream audience, it seems appropriate on this kind of recording that he provides exposure to those fiddlers who spend more of their time on the Island, and make more of their living by playing local contexts rather than international tours.

One of my favourite tracks is that of Kinnon and Betty Beaton playing for a dance at the Mabou Hall. The recording captures the third figure of the dance, called or prompted by Owen D. Gillis. The art of prompting has now all but vanished on Cape Breton, making this an important historical documentation, and providing the listener with an alternative way of experiencing the dance context. Other favourites include the jig medley by Wendy MacIsaac (she is my all-time favourite Cape Breton fiddler), and Buddy MacMaster's "Devil in the Kitchen." I have several recordings of Buddy playing this tune, some commercial and others homemade. Each rendition is slightly different, demonstrating this Cape Breton icon's mastery of fine variation and ornamentation.

The big draw of this CD is, of course, that it is recorded live. We hear the feet stomping, the hoots and hollers, the applause. The musicians seem alive to me, and I am drawn back to my own memories of evenings on the dance floor in Mabou or Brook Village. It is tempting to fall into the trap of romanticizing the atmosphere of a live context, and one can hardly fault the producer, Burt Feintuch, for heading in that direction:

This is not the pristine sound of studio recordings. It's the sound of real people playing music hard, of people moving their bodies to the music's pulse in halls and on stages in small communities. There's a 
drive and energy in these recordings that comes from playing for people, not for microphones. It's the sound of the music when it's at home. At a time when Cape Breton fiddle music's increasing popularity leads some to worry that it's losing it's traditional sound, we wanted to document the music in local settings. We were lucky — we recorded extraordinary musicians playing from the heart, playing in the hotbed of the music. This is the real thing (p.4).

Had he stopped before the last sentence, I could have let it go without comment; however, the implication that this music is real in a way that other recordings are not seems to me to be rather misleading, and even potentially harmful to the cause of traditional music. While those of us well-versed in scholarly debates of authenticity add quotation marks around "real," and understand it to be a symbolic construct, the majority of the public, and I would suspect a large part of the audience for this recording, understand real to be the opposite of unreal, or artificial, or inauthentic: "However effectively scholars deconstruct authenticity and reveal it to be an intellectual red herring, the concept remains nonetheless entrenched in popular thought and is an emotional, political issue..." (Linniken 1991: 446). Creating, or at least maintaining, this imaginary division between real and unreal / artificial / inauthentic experiences of Cape Breton fiddling disregards the variety of ways that cultural forms and activities are understood by both their practitioners and audience. While I, and I would suspect the majority of Cape Breton fiddlers and fiddle fans, appreciate the atmosphere created in the live recording, there will be others, perhaps from other fiddle or music traditions, with different aesthetic preferences; their experiences are equally real and authentic, just different. There is much to be learned from a variety of recording situations and concepts.

"Cape Bretoners talk about their music representing a purer and older Scottish style and repertoire than the music played these days in Scotland" (5). Likewise, Cape Breton fiddle scholars have tended to focus on its Scottish roots, and that which has stayed the same in the music (Dunlay and Greenberg 1996; Dunn 1991; Garrison 1986; an exception is Doherty 1996) rather than the creative and vibrant contemporary scene, for example the rich compositional activity occurring in this tradition. Feintuch is careful to acknowledge that Cape Breton fiddling is not a pure, unchanging remnant of an earlier Scottish style of fiddling: 
At a time when the transnational Celtic revival is tending to blur regional styles, Cape Breton music has held on to its distinctiveness. Rooted in emigration and incubated by relative isolation, the music is strongly tempered by its roots in Scots Gaelic culture. At the same time, it's a music that has been able to change... [T]his music has remained vital thanks in large measure to the way the musicians, always tempered by their communities, have been able to embrace creativity while not losing the music's traditional essence. The essence is not one thing... $(6-7)$

At the same time, Feintuch does not shy away from the traditional nature of this music: Buddy MacMaster "stands for the tradition" (21); accompanist Joey Beaton is "a strong traditionalist" (21); Jerry Holland's rendition of two well-known strathspeys and reels, played "in high bass, is a powerful statement of traditional values" (21); Wendy MacIsaac is "a versatile musician with a strong commitment to the tradition" (24). Balancing the importance of "tradition" and roots with the creativity and innovation of contemporary musicians is a difficult task for all those working with traditional musics; it is a balance that Feintuch negotiates with considerable skill.

The relationship between the older tradition and contemporary practice is illustrated in an anecdote from Reiniger's description of his recording technique. He writes that because he assumed he would be recording acoustic instruments, he did not take any direct boxes to record the electric signals of fiddle transducers and electric keyboards, which are now the predominant means of amplifying instruments in Cape Breton. Luckily, he was able to find the necessary equipment at a Sydney music store, and the project continued.

The non-studio context of The Heart of Cape Breton: Fiddle Music Recorded Live Along the Ceilidh Trail is shared by a series of recordings recently released in the North American Traditions Series from Rounder Records (http://www.rounder.com/rounder/nat/nat_new.html), in which fiddlers are recorded primarily in their homes in Cape Breton, Toronto, and Detroit. The goal of this multi-volume collection, produced by Mark Wilson and Morgan MacQuarrie, is to document and expose listeners to "old style Scots music" before it disappears. The series features a number of Cape Breton fiddlers: volume one features fiddlers from around Mabou, Inverness County, and volume two includes fiddlers from north of the Lake Ainslie area (both released in September 2002). 
Future volumes will include both individual fiddlers and further anthologies. Feintuch mentions this series as "a field-recorded effort" (13) that complements his own.

This recording has quickly become one of my favourites: the opportunity to hear six of Cape Breton's best fiddlers on one CD; the incredible energy and drive in the playing; the excitement and appreciation of the, mostly dancing, audience; and the memories it evokes of one of the best weeks in my life. The essay and notes by Burt Feintuch provide a deeper understanding of this unique fiddling tradition to those at all levels of familiarity with it. Beyond the usual recommendation of this recording to fans of both fiddling and Cape Breton music in general, this CD will be of interest to folklorists and ethnomusicologists interested in the presentation of an audio documentary of a particular place and time.

\section{References}

Doherty, Elizabeth Anne. 1996. The Paradox of the Periphery: Evolution of the Cape Breton Fiddle Tradition 1928-1995. Ph.D. diss., University College of Cape Breton.

Dunlay, Kate and David Greenberg. 1996. Traditional Celtic Violin Music of Cape Breton. Toronto: DunGreen Music.

Dunn, Jacqueline Ann. 1991. Tha Blas na Gaidhlig air a h-uili Fidhleir [The Scottish Accent in the Fiddle]. B.A. thesis, St. Francis Xavier University.

Garrison, Virginia Hope. 1986. Traditional and Non-traditional Teaching and Learning Practices in Folk Music: An Ethnographic Field Study of Cape Breton Fiddling. Ph.D. diss., University of Wisconsin, Madison. Linnekin, Jocelyn. 1991. "Cultural Invention and the Dilemma of Authenticity". American Anthropologist 93: 446-9. 